\title{
WISE方式小企業職場改善トレーニングの 継続的効果について
}

小木 和孝、川上 剛（労働科学研究所）、井谷 徹（名古屋市大·医・衛生）

Sustained effects of workplace improvement training in small enterprises applying WISE (Work Improvement in Small Enterprises) methodology Kazutaka Kogi, Tsuyoshi Kawakami (Institute for Science of Labour),

Toru Itani (Nagoya City University Faculty of Medicine)

\section{1.はじめに}

小企業の職場改善では、その小企業の特性 を配慮して実施可能な改善に力点をおくすす め方が効果的であることが、内外の経験から 知られてきた。急速な工業化のもとで整備遅 れが問題とされるアジア諸国の小企業でも、 多面の改善策を参加型で実施する方法が有効 だと確かめられている。そのよい例が I L O がアジアや南米で普及をはかっている WISE (Work Improvement in Small Enterprises) 方式 の小企業改善トレーニングである。

とくにフィリピンで1994年以降行われた WISE活動では、参加型トレーニング方式の採 用によって、多数の中小企業で自主的職場改 善が実施された。それに多くの人間工学改善 が含まれる。その後のフォローアップ結果か ら、継続的効果を生む要因として (1)実施可能 なシンプル改善の支援、(2)人間工学要因の幅 広い取り上げ、(3)生産性向上と連係した自主 改善の重視が注目される。

\section{2. すぐのシンプル改善の支援}

WISE方式職場改善では6原則として、(a)地 域慣行から出発、(b)実績に焦点、(c)経営目標 との関連づけ、(d)” 実行して学ぶ”、(e)地元 経験の交流、(f) 労働者の参加をあげる。この 6 原則が継続的効果を生む背景になる。

この方式によるトレーニングの参加者のア ンケート結果から、表 1 に示したトレーニン グの諸ステップがすぐの改善実施を促したと みることができる。上記 6 原則を生かしたこ れらのステップが、トレーニング後の継続的 効果にもよい影響をおよほしたとみられる。 とくに、地元改善実例とチェックリスト利用 によって小企業で実施可能な多面改善策を学 んだことがよかったとの意見が多い。グルー プワークによる改善策の自主選定で自助の有 効性を確かめえた点も高く評価されていた。
表 1.WISE方式小企業トレーニングのステッ プとその継続的効果への影響

トレーニングステップ＼cjkstart継続効果への寄与

(1)地元改善実例に学ふ

(2)チェックリストで実 施可能策を検討する

(3)対話で改善を計画

(4)低コスト中心の合意 策をすぐ実施する

実施可能性の確認 対策指向の多面的 改善視点の学習 優先策の自主選定 低費用と自助成果 の重視

そうしたステップによる短期のトレーニン グ効果をみると、すぐの改善実施率が高い。 表 2 にフィリピン 4 地域における 3 年間の成 果を示した。いずれの改善領域でも、グルー プワークで合意した提案の $80 \%$ 内外が10日間 前後のトレーニング期間中に実際に実施され たこの事実が継続的効果に有利とみられる。

表 2.フィリピンにおける1994-96 年の小企 業WISEトレーニング活動による改善結果

\begin{tabular}{lcc}
\hline 改善領域 & 改善提案数 & コース中実施数 \\
\hline 資材運搬移動 & $409(100)$ & $364(89)$ \\
作業台設計 & $167(100)$ & $134(80)$ \\
機械の安全 & $166(100)$ & $142(86)$ \\
有害源の隔離 & $116(100)$ & $98(84)$ \\
照明 & $260(100)$ & $225(87)$ \\
休盖衛生施設 & $239(100)$ & $196(82)$ \\
構内の整備 & $482(100)$ & $373(77)$ \\
作業組織 & $185(100)$ & $150(81)$ \\
環境保護 & $46(100)$ & $43(93)$ \\
\hline 合計 & $2070(100)$ & $1725(83)$ \\
\hline
\end{tabular}


3. 企業内人間工学要因の多面取り上げ

こうしたトレーニングでは、小グループご とに低コスト改善策を提案しすぐ実施する。 この過程で各企業内の人間工学要因を多面に 取り上げるのが、どのコースでも共通してい た。多面的改善がこの方式の大きな特徵であ るが、その実績が継続的効果につながる。表 3 に示したセブ島コースでは、20企業参加で 108の改善が提案され、4 件以上の改善を企 画した企業が70\%もあった。改善領域が多面 にわたるのが常であり、 4 件以上の企業では 改善が $3 〜 7$ 領域にわたっていた。

表 3. セブ島での各小企業内の改善数の分布

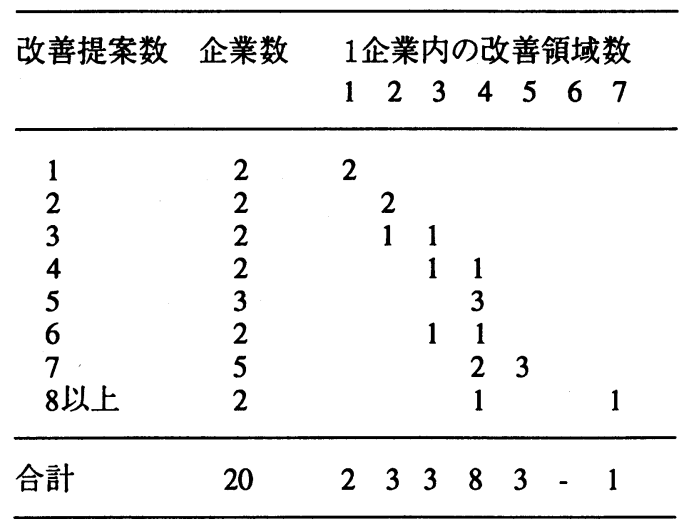

\section{4. 生産性向上と連係した自主改善}

このセブ島コースの 1 年後のフォローアッ プ結果が表 4 である。1 年後にこの 61 の実施 済み改善の内 43 件 (70\%) が改善効果を維持 していた。進行中が18件残され、改善中止は 12件に止まっていた。この間に新たな改善が 10件行われていたことが注目される。

これらの改善点は運搬移動やワークステー ション改善、作業環境や休養衛生施設など、 直接間接に生産性向上に役立つものが多かっ た。とくに運搬車や保管ラックの導入、通路 の改善、作業面の高さの適正化、作業位置か らのリーチや工具の改善、照明、グループ作 業などが継続的効果をもちやすかった。また 回転作業台、副作業台の活用、工具や材料供 給装置改善など現場の工夫も多くみられた。

フィリピンのWISE方式トレーニング後の事 例調査から、改善が企業単位の生産性向上に よい影響を及ほしたことが知られた。生産工 程・労働者・作業環境・経営管理の計 27 項目 について 5 段階評定した結果をまとめた生産
表 4. 七ブ島コースにおける改善提案108件 の 1 年後のフォローアップ結果

\begin{tabular}{lrrrrr} 
改善領域 & $\begin{array}{c}\text { コース中実施の } \\
\text { 改善(1年後継続) }\end{array}$ & $\begin{array}{c}\text { 中止 } \\
\text { 中 }\end{array}$ & $\begin{array}{l}\text { 進行 } \\
\text { 中 }\end{array}$ & $\begin{array}{c}\text { 新規 } \\
\text { 改善 }\end{array}$ \\
\hline 運搬移動 & $12(6)$ & - & 2 & 2 \\
作業台設計 & 6 ( 5) & 3 & 6 & 2 \\
機械の安全 & $6(6)$ & 3 & & \\
有害源隔離 & $12(5)$ & - & 3 & 2 \\
照明 & $6(4)$ & 2 & 2 & \\
福利施設 & $4(4)$ & - & 1 & \\
構内の整備 & $12(12)$ & 3 & 3 & 1 \\
作業組織 & $3(1)$ & 1 & 1 & 3 \\
\hline 合計 & $61(43)$ & 12 & 18 & 10 \\
\hline
\end{tabular}

性評点を改善前後で比較すると、10例（食品 製造業・金属製品製造業・縫製業）の全例で 評点が上がった。改善前の評点2.59 3.54 (平均3.06) が改善後に2.73 3.65 (平均 3.28）になった。金属製品製造では、作業面 の高さ、炬環境・照明の改善、作業用ラック の増設、衛生設備の改善等が有効であった。

このように生産性向上と連係した多面の改 善を現場の自主活動で図ることが継続的効果 に結びつきやすいと考えられた。低コスト策 に集中することがそれを促進する。WISE方式 職場改善の利点は、この点に集約できよう。

\section{5，まとめ}

対策指向型のチェックリストを用いた参加 型トレーニング方式を途上国小企業に応用し た結果、自主改善が多数実施され、継続的効 果があることが確かめられた。シンプル改善 を多面の人間工学領域で取り上げ、優先低コ ス卜策を自主選定する“実践して学ふ”方式 が継続的効果に結びついていくとみられる。

\section{参考文献}

1) J.E. Thurman, A.E. Louzine, K. Kogi: Higher Productivity and a Better Place to Work: Trainers' Manual, ILO, Geneva, 1988.

2) K. Kogi: Participatory ergonomics that builds on local solutions, J. Human Ergol., 24, 37-45, 1995.

3) K. Kogi, T. Kawakami: Current research: ergonomics(Occupational and environmental health in the Asia-Pacific region), Env. Management and Health, 8, 188-190, 1997. 